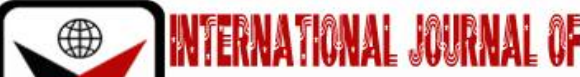

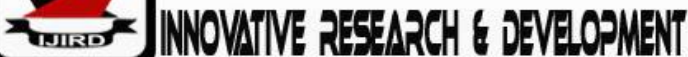

ISSN 2278 - 0211 (Online)

\section{Profit Ability of Fresh Fish Marketing in Bauchi Metropolis, Bauchi State, Nigeria}

Dr. Madaki M. J.
Lecturer, Department of Agricultural Economics and Extension,
Federal University Gashua, Nigeria
Abba Y.
Lecturer, Department of Agricultural Technology,
College of Agriculture Gujba, Yobe State, Nigeria
Dr. Bose A. A.
Lecturer, Department of Agricultural Economics and Extension,
Abubakar Tafawa Balewa University Bauchi, Nigeria
Samaila M.
Lecturer, Department of Agricultural Technology,
College of Agriculture Gujba, Yobe State, Nigeria

\section{Abstract:}

The study examined the profitability of fresh fish marketing in Bauchi Metropolis, Bauchi State, Nigeria. Data were collected using questionnaire from 90 fish marketers selected randomly. Descriptive statistic and market margin analysis were used to analyze the data. The results indicated that majority (76.7\%) of the marketers were female while $23.3 \%$ were male. The years of marketing experience indicated that $45.6 \%$ had marketing experience of $1-10$ years. Age of the marketers indicated that $54.4 \%$ of the marketers had ages, which ranged from 21 - 30 years. Majority (43.3\%) of the marketers had tertiary education and only $1.1 \%$ of the respondents had adult education. The average marketing margin stood at $25.35 \%$ and the average gross margin was $N 41.45$. The result further revealed that the average marketing efficiency was $147.2 \%$ and the average return to naira invested was 0.27 Problems associated with fish marketing included inadequate storage facilities (96.7\%), high cost of transportation (87.8\%) and lack of standard unit of measurement (47.8).Among others; the study recommends that formation of co-operative societies should be encouraged to help in the provision of storage facilities and vans for the transportation of fresh fish in good time.

Keywords: Fresh fish, marketing, Bauchi, Nigeria

\section{Introduction}

Fish has been to be the cheapest source of protein in the diet of average Nigerians as it contributes about $40 \%$ of the total animal protein intake (NADC, 2011 FOA, Oyenuga, 2009). There is also high rate of rural-urban migration, high price of food items and precautions food security situation. This makes citizens vulnerable to dietary association diseases. The inability of Nigerians to meet their protein requirement could be linked to their poverty levels. Animals protein sources such as beef, mutton and chicken are beyond the reach of an average income earner, he therefore concentrated to fish being the cheapest among the animal's protein source (Yonoba,2001).

Fish is becoming more and important source of vulnerable protein food. It occupies a unique position in the diet of average Nigerians as it contributes about $45 \%$ of the total animal protein intake and can supplement lysine deficiency in cereals (FAO, 2001). More than half of the world population depends on fish as principle source of animal protein and in many countries, people derived more than their daily animal requirement from fish thus, fish is regarded as the single most important food component that supplies the bulk country's animals protein which are rich in essential amino acid. More so, there are fewer or no religious or social taboos associated with fish consumption as opposed pigs and other livestock.

Fish marketing involved an alternative means of making fish available to man since the quantity and quality of fish in Nigeria has been compromised by over fishing over increasing human population and incessant water pollution among other factors which have make fishing a very difficult expensive task, fish marketing becomes imperative (Yemi $e t$ al, 2006).

In Bauchi metropolis fresh fish (Clarians gariepinus\} marketing is very common because it is the most common fish stocked in the area. Fresh fish [Clarians gariepinus] has been considered to produce high yield for fishery industry 
in Africa. The African fresh fish has high growth rate it is very resistant to handling and stress and is very well appreciated in a wide number of African countries including Nigeria (John, 2006, Oguche, 2005).

Moreover, agricultural marketing is an integral part of national development in Nigeria. It is imperative to assess fish marketing in order to satisfy the nutrition requirement in terms of quantitative source of protein to consumer as well as to improve the income of fish marketer the study also provided information for decision making, planning and protein to consumers. For these reason it is important to examine the economics offish marketing in Bauchi metropolis. The low animal's proteins intake brought about increase in production and marketing of fish in value of fish and marketing attracted the attention of good number of researchers. Such effort is equally needed on marketing of fish which link between production and consumption. Also since it is source of income to both producers and marketers there is need to study its profitability,

In marketing, fresh fish passes through various market participants and exchange points before they reach the final consumers. These market intermediaries are the whole-sellers and retailers. Both play an important role in the marketing system. At all stages in the marketing chain, fish has to be packed and un-packed, loaded and un-loaded to meet consumers demand. Each handling cost will not amount to much but the sum total of all loading can be significant, depending on the length of chain. This makes a greater difference in price paid between urban consumers and at the end of the chain and farm gate price at the beginning of the chain. This can lead to a greater or wider market margin between the producer and the final consumers. If the market margin is high, it may be used to argue that producers or consumers are being exploited. However, high margin cannot often be fully justified unless the costs involved are fully understood and reasonable. In the area of marketing, empirical research (Hassan et al., 2005; Maqbool et al., 2005; Ali \& Iheanacho, 2007)on other agricultural commodities was carried out but none captures fresh fish marketing in the area included in this study.

The main objective of the study is to assess the profitability of fresh fish marketing in Bauchi Metropolisin Bauchi State, Nigeria. The specific objectives are:

- Determine the socio-economic characteristics of the fresh fish marketers in the studyarea.

- $\quad$ Examine the profitability level of fresh fish marketing in the study area.

- Identify the constraints affecting fresh fish marketers in the study area.

\section{Methodology}

\subsection{The Study Area}

Bauchi state is situated between latitudes $9^{\circ} 30^{\prime}$ and $12^{\circ} 31^{\prime}$ and longitudes $8^{\circ} 50^{\prime}$ and $11^{\circ} 50^{\prime} \mathrm{E}$ of Greenwich meridians with a total land area of about 46,000 square kilometers while Bauchi Local Government Area lies between longitude $10^{\circ} 10^{\prime} \mathrm{N}$ and $10^{\circ} 33^{\prime} \mathrm{N}$ and Latitudes $9^{\circ} 40^{\prime} \mathrm{E}$ to $10^{\circ} 13^{\prime} \mathrm{E}$. Its altitude is $690.2 \mathrm{~m}$ above sea level. Bauchi local government is located in the northern and Sudan savanna zones of northern Nigeria. The local government has 75 to $80 \%$ of its land area as cultivable out of which about 150,000 hectares is suitable for Fadama (Irrigation) farming. Over $85 \%$ of the population is peasant agrarian and rural based whose farming system is mainly mixed farming with small holdings of about 3-5 ha per farm family (BSADP, 2004).The population of Bauchi Local Government in 2006 according to National Population Commission was 493, 810.The major economic activity of the people of the metropolis is agriculture and trading. The major crops grown are sorghum, millet, rice, Hungary rice, cowpea, maize, groundnuts. The following Animal production components are also carried out: cattle rearing, goat production, ram fattening and poultry keeping among others.

\subsection{Sampling Procedure and Sample Size}

Purposive sampling technique was used in selecting four markets which include Muda-Lawan, Wunti, Central and Yelwan Tudu markets. Majority of the population of catfish marketers were included in this study to broaden the number of respondents in order to enhance the accuracy of results. This is because fresh fish marketing is a recent development and a large number of fresh fish marketers have few years of marketing experience. The marketers were selected using simple random techniques with the aid of table of random numbers. In Muda-Lawan market, 40 traders were selected, in Central market 20 traders were selected, while in Wunti market 20 traders were selected and in Yelwan Tudu market 10 traders were selected. This gave a total sample of 90 traders in the study area.

\subsection{Method of Data Collection}

The data used for this study were obtained by means of structured questionnaires administered to 90 respondents (catfish marketers). The questionnaire was divided into two (2) sections. The first section covered the socioeconomic characteristics of the respondents while the second section covered the marketing data of the respondents which includes- source of supply, the costs and returns and also the constraints militating against fresh fish marketing in the study area.

\subsection{Analytical Techniques}

The analytical tools used in this study include; simple descriptive statistics which comprises percentage, mean and frequency; and Farm budgeting model. Descriptive statistics was used to analyzed the socio-economic characteristics of the respondents and the problems associated with fresh fish marketing. 


\subsection{Gross Margin Analysis}

Gross margin has been widely used by researchers to determine the profitability of a farm. This model was used in this study to determine the costs, returns and profitability of the fresh fish marketing enterprise in the study area.

The gross margin analysis model is specified as the component of farm budget model which is given as:

$$
G M=G I-T V C \text {. }
$$

Where $\mathrm{GM}=$ Gross margin analysis

$\mathrm{GI}=$ Gross income (Total Revenue) from fresh fish marketing

TVC = Total variable cost from fresh fish marketing.

Return per Naira Invested $(\mathrm{RNI})=\frac{N I}{T V C}$

Where $\mathrm{NI}=$ Net Income

TVC = Total variable cost from fresh fish marketing.

\subsection{Market Efficiency}

This is the ratio of maximization of output to input in a marketing system. Marketing efficiency is the ratio of valued added to fresh fish to the marketing cost.

Where:

$$
M E=\frac{V A}{M C}
$$

$$
\begin{aligned}
M E & =\text { Marketing Efficiency } \\
V A & =\text { Valued added on fresh fish marketing. } \\
\text { MC } & =\text { Marketing Cost }
\end{aligned}
$$

\subsection{Marketing Margin}

Market margin is the difference in price paid for a given commodity as it moves from one stage to another within the market chain.

$$
M M=\frac{R P-P P}{R P} \times 100
$$

Where: $\mathrm{MM}=$ Marketing Margin

$\mathrm{RP}=$ Resale price of fresh fish

$\mathrm{PP}=$ Purchased price of fresh fish

\section{Results and Discussion}

\subsection{Socio-Economic Characteristics of the Respondents}

The socio-economic characteristics of respondent play an important role in the marketing operation. It is expected that older marketers are experienced in marketing activities than the younger ones.

The Socio-economic characteristics of the respondents are presented in table 1 . The table 1 shows that majority of respondents (54.4\%) fell within the age of 21 - 30years, $32.2 \%$ of them fell within the age of $31-40$ years. Also $10.0 \%$ of the respondents fell within the age of $41-50$ years and 3.33\% were within the age group of $51-60$ years. The result implies that majority of the respondent are in their active age of marketing, while 51 - 60 years constitute the lowest due to risk aversive. The average age of the respondents was 31.7 which shows that the respondents are in their age of production. The table also shows that majority of the respondents $(76.7 \%)$ were female and $23.3 \%$ were male indicating that fresh fish marketing in the study area was to a great extend being carried out by female while the male have been left out constituting less half of the market population. The results further revealed that majority of the respondents $(61.1 \%)$ were married while $38.9 \%$ of the respondents were single. The implication of the result indicate that undoubtedly marital status determine the size of the family which influences the decision making of fresh fish marketing in the study area. Married people were found to have the largest family size. The tables show that $46.7 \%$ have the family size within the range of $6-10,37.11 \%$ had household size between $1-5$ and also $14.4 \%$ range between $11-15$. The remaining of the household size of the respondent's range between $16-20$. The result implies that most of the respondents are Muslims were a man can marry more than one wife. The table 5 shows that $45.6 \%$ of the respondent fell between 1 - 10years of experience, $34.4 \%$ had $11-20$ years of experience. The table also shows that $17.8 \%$ had experiences of $21-30$ years while $2.2 \%$ had the experience of $31-40$ years. The average mean of years expected was 13.2. The implication of this finding is that most of the respondents in the study area has reasonable years of experience in the marketing of fresh fish.The result shows that $43.3 \%$ of the respondent had tertiary education, $26.67 \%$ of the respondent had primary education, and similarly $11.1 \%$ had secondary education while $1.1 \%$ of the respondents had adult education. This implies that majority of the fresh fish marketers are literate and can easily accept new techniques of marketing and can make proper decision in their marketing activities in the study area. The result in Table 1, shows that $33.3 \%$ of the marketers were involved in fresh fish marketing only and $28.9 \%$ were involved in fresh fish marketing and civil service, $22.2 \%$ of them involved in fresh fish marketing and farming, while $15.6 \%$ of them involved in fresh fish marketing and other product. The result implies that majority of the respondent in the study area are involved in the marketing of fresh fish and other forms of economic activities. The Table further shows that $46.7 \%$ of the marketers starts with total volume of capital of N1000 20,000 and $30 \%$ of them starts with capital range from $21,000-40,000,11.1 \%$ of them handle the business with the capital of $61,000-80,000$ and $6.67 \%$ of the respondent handle the business with a capital of $81,000-100,000$. The mean of the capital invested was N5, 3911.1. The implication is that most of the marketers are medium-scale marketer (retailers) 


\begin{tabular}{|c|c|c|}
\hline Variables & Frequency & Percentage \\
\hline \multicolumn{3}{|l|}{ Age(Yrs) } \\
\hline $21-30$ & 49 & 54.4 \\
\hline $31-40$ & 29 & 32.2 \\
\hline $41-50$ & 9 & 10 \\
\hline $51-60$ & 3 & 3.4 \\
\hline \multicolumn{3}{|l|}{ Sex } \\
\hline Male & 21 & 23,3 \\
\hline Female & 69 & 76.7 \\
\hline \multicolumn{3}{|l|}{ Marital Status } \\
\hline Married & 35 & 38.4 \\
\hline Single & 55 & 61.6 \\
\hline \multicolumn{3}{|l|}{ Household size } \\
\hline 01-May & 34 & 37.1 \\
\hline 06-Oct & 45 & 46.7 \\
\hline Nov-15 & 10 & 14.4 \\
\hline $16-20$ & 1 & 1.1 \\
\hline \multicolumn{3}{|l|}{ Marketing Experience (Yrs) } \\
\hline $01-$-Oct & 41 & 45.6 \\
\hline Nov-20 & 31 & 34.4 \\
\hline $21-30$ & 16 & 17.8 \\
\hline $31-40$ & 2 & 2.2 \\
\hline \multicolumn{3}{|l|}{ Educational level } \\
\hline Quaranic & 11 & 12.2 \\
\hline Primary & 24 & 26.8 \\
\hline Secondary & 10 & 11.1 \\
\hline Tertiary & 39 & 43.3 \\
\hline Adult & 1 & 1.1 \\
\hline \multicolumn{3}{|l|}{ Occupation } \\
\hline Fresh Fish marketing only & 30 & 33.3 \\
\hline $\begin{array}{l}\text { Fresh Fish marketing and } \\
\text { farming }\end{array}$ & 20 & 22.2 \\
\hline $\begin{array}{l}\text { Fresh Fish marketing and } \\
\text { other product }\end{array}$ & 14 & 15.6 \\
\hline $\begin{array}{l}\text { Fresh Fish marketing and } \\
\text { civil service }\end{array}$ & 26 & \\
\hline
\end{tabular}

Table 1

Source; Field Survey 2018

The average costs and returns of fresh fish marketing in Bauchi Metropolis markets are presented in table 2. The results in Table 2 show that the average total marketing cost per kg was N88.55. The total variable cost and the total revenue were N471.05 and N512.5, respectively. The marketing margin was found to be $25.35 \%$ while the gross margin was $\mathrm{N} 41.45$, and the return per naira invested was 0.27 with a marketing efficiency of $147.2 \%$. This implies that in every naira the marketer invested in fresh fish marketing he/she realized a return of $\$ 0.27$. Thus fresh fish marketing is a profitable business. This result is in agreement with the findings of Idris (2014) who disclosed that fresh fish marketing is profitable. 


\begin{tabular}{|c|c|c|}
\hline Items & Amount (N) & Percentage \\
\hline Variable cost & - & - \\
\hline Purchased priced & 382.5 & 80.50 \\
\hline Transport & 17.25 & 4.38 \\
\hline Loading and offloading & 20.75 & 4.63 \\
\hline Commission fees & 35.25 & 3.22 \\
\hline Tax/Revenue & 13.87 & \\
\hline Total marketing cost & 88.55 & \\
\hline Total variable cost & 471.05 & \\
\hline Total revenue (Gross income) & 512.5 & \\
\hline Marketing margin & $25.35 \%$ & \\
\hline Gross Margin & 41.45 & \\
\hline Return per naira invested & 0.27 & \\
\hline Marketing efficiency & 147.2 & \\
\hline Table 2 Average Costs and Returns & \\
\hline
\end{tabular}

Table 2: Average Costs and Returns on Fresh Fish Marketing in

Bauchi Metropolis Markets per $\mathrm{Kg}$ (Retailer)

Source: Field Survey, 2018

\subsection{Problems of Fresh Fish Marketing}

\begin{tabular}{|c|c|c|}
\hline Problems & Frequency & Percentage \\
\hline Inadequate capital & 32 & 35.5 \\
\hline High cost of transportation & 79 & 87.8 \\
\hline Lack of standard unit of measure & 43 & 47.8 \\
\hline Inadequate market infrastructure & 19 & 21.1 \\
\hline Instability of market price & 24 & 26.7 \\
\hline Inadequate/poor storage facilities & 87 & 96.7 \\
\hline Adulteration of fish & 8 & 8.9 \\
\hline Others & 5 & 5.6 \\
\hline Total & $297^{*}$ & $330.2^{*}$ \\
\hline
\end{tabular}

Table 3: Distribution of Respondents According to the Problems

Affecting Fresh Fish Marketers in the Study Area

* Multiple Respondents Were Obtained

Source: Field Survey, 2018

The results in the Table 3 show that $96.7 \%$ of the respondents acknowledged poor storage facilities which result in the spoilage of fish as the major problem and this affected the performance of their business. Also 87.8\% of the respondent complained about high cost of transportation as a result of high amount is charges per carton in transporting the fish from the farm to the market and due to poor road that link the farm to the market metropolis. In addition, $47.8 \%$ of the respondent complained about lack of standard unit of measurement and 35.5\% of them complained about inadequate capital that most of their capital is raised by personal saving and also loan from financial institution is very difficult. Also the results reveal that $26.7 \%$ of the respondents complained about price fluctuation of fresh fish in the market, the price of fresh fish is low during the rainy season and the income received by the marketers is very low compared to the one received in dry season. Further, $21.1 \%$ complained about market infrastructure and $8.9 \%$ of the respondent complained about adulteration of fish that inferior and superior fresh fish is mixed in the same carton and sold to them as superior fish. This finding is in line with Ahmad (2000) who reported that poor storage was the major problem of cat fish marketing in Bauchi State.

\section{Conclusion}

A critical appraisal of fresh fish marketing in Bauchi metropolis is profitable. As fish is perishable it needs to be handled with care in order to avoid losses. The perish ability and seasonality of fish result in price fluctuation which neither favour the marketers nor the consumers. These factors had led to high cost to consumers and affect the volume produced.

\section{Recommendations}

Based on the findings of this study, the following recommendations were made:

- The marketers should form cooperative societies in order to have easy access to formal credits facilities.

- Marketers should be encouraged to adopt the use of modern storage facilities for efficient preservation of their fish.

- Government should construct and/or rehabilitated the rural feeder and urban roads. This may help in reducing the transportation of fresh fish to the urban centre.

- Credit facilities should be made available to supplement marketers personal saving. This can be done by revitalizing agricultural bank and encouraging cooperative societies in the study area. 


\section{References}

i. Ahmad, M.A. (2000). The aim of market structure information system. A Journal of Agricultural Products $5^{\text {th }}$ Edition Macmillan CO, New York, U. S. A., 612 pp.

ii. FAO (2011). Liberalizing Tangamia fish marketing, public and private faces of urban marketing policy a paper presented at 2004 Annual conference held at university of Maiduguri, Borno state, Nigeria. 4 - 6volume.

iii. FAO (2001). Fish and Sea food in Human Nutrition in the Developing World and Agricultural Organisation and Nutrition paper No. 29, 283pp.

iv. Idris, A.M. and Ajana, A.M. (2014). Fresh fish marketing and products: paper presented for in-service training at Agricultural Extension and Research Liason Services, ABU Zaria Nigeria. 10 pp.

v. John, M.O. and Nenna, M.G. (2006). Urban aquaculture in Nigeria, world aquaculture society. Annual report www.was.org/meetings/abstractdata.

vi. NADC (2011) Opportunities in aquaculture focus. Vol. I, No. I page 10. Agricultural Journal published by Foundation Consultants Limited, Abuja October Edition.

vii. Oguche, M.A. and Ozo, N. (2005). Economic Analysis of Catfish Marketing in Bauchi State: Unpublished Bachelor of Technology project Submitted to the Agricultural Economics and Extension Department Abubakar Tafawa Balewa University, Bauchi 73pp.

viii. Oyenuga, N.C. and Ogungbameru, 0.0. (2009). The significance of Fresh fish preservation and processing in the Development of Nigeria.

ix. Yemi, M.A. and Olumide, T.O. (2006). Economic Analysis of fish marketing and resources used Journal of Economics Vol. 46, pp 295 - 297.

x. Yonoba, M.C. (2001). Fisheries management in the Federal Republic of Nigeria www.foa.org/fi/fcp/en/NGA.

xi. Zakari, A.H. and Idris, M.H. (2004). The Economics of wholesale marketing of processed fish in Oweri area of southern Nigeria. The Journal of the Faculty of Agriculture, Published by the UWI 70(4): 139. 